\title{
Maternal and fetal outcomes with the use of prostaglandins E2 as a cervical ripening agent for induction of labour
}

\author{
Shagun Gupta ${ }^{1}$, Neha Kuntal ${ }^{2 *}$, Virendra Kumar Gupta ${ }^{3}$
}

\begin{abstract}
${ }^{1}$ Department of Obstetrics and Gynecology, NIMS University, Jaipur, Rajasthan, India
${ }^{2}$ Department of Obstetrics and Gynecology, SMS Medical College, Jaipur, Rajasthan, India

${ }^{3}$ Department of Pediatrics and Gynecology, NIMS University, Jaipur, Rajasthan, India
\end{abstract}

Received: 17 November 2019

Accepted: 03 December 2019

\author{
*Correspondence: \\ Dr. Neha Kuntal, \\ E-mail: nehakuntal88@gmail.com
}

Copyright: ( $\odot$ the author(s), publisher and licensee Medip Academy. This is an open-access article distributed under the terms of the Creative Commons Attribution Non-Commercial License, which permits unrestricted non-commercial use, distribution, and reproduction in any medium, provided the original work is properly cited.

\begin{abstract}
Background: In modern medicine induction of labour is required in patients for a good feto-maternal outcome. PGE2 is a prostaglandin analogue which has been used as a cervical ripening agent to improve bishops score. Objective of this study was to evaluate the efficacy of intravaginal PGE2 gel as a cervical ripening agent in unfavourable cervix for induction of labor and any complications associated with its use.

Methods: This study comprised of 90 women who required labor induction. Singleton pregnancy above 37 weeks, live intrauterine fetus, Cephalic presentation, Bishop score of 1-6, reactive FHR pattern were included. Women who required only single induction were categorized as Group 1. Those requiring more than one dose after reassessment of bishops scoring at 6,12 and 18 hours belonged to Group 2.

Results: Group1 had more of younger population below 30 years consisting more primigravidas with $>80 \%$ women having gestational age of $>39$ weeks. Most common indication for induction of labour in both groups was post-dated pregnancy. 65 patients received one dose of cerviprime gel forming Group 1. In Group 2, $72 \%$ received 2 doses and $28 \%, 3$ doses of gel. Initial bishops score mean was 4.2 in Group 1 and 4.1 in Group 2. Mean change in bishop score was analysed after 6,12, and 18 hours of instillations of PGE2 gel. Significant p value was obtained in all groups requiring one, two and three doses of gel. In Group 1, 12.3\% and in Group 2, 16\% had LSCS. Maternal side effects were minimal and neonatal outcome was good.

Conclusions: The study showed that intravaginal application of PGE2 is effective, safe and acceptable method as a cervical ripening agent for labor induction in women with poor bishops score. It reduces caesarean delivery rate without increasing maternal and neonatal morbidity.
\end{abstract}

Keywords: Bishops score, Caesarean section, Intravaginal prostaglandin E2, Induction of labour

\section{INTRODUCTION}

In the era of modern medicine, with the increasing awareness over the past few years, labour is often induced to decrease risk of maternal or neonatal morbidity and mortality. In case of unfavourable cervix, a successful vaginal birth is less likely. Bishop developed a standardized cervical scoring system for cervical assessment. The duration of labor is inversely correlated with the Bishop score; a score that exceeds 8 describes the patient most likely to achieve a successful vaginal birth. Bishop scores of less than 6 usually require that a cervical ripening method be used before other methods. ${ }^{1,2}$

Pharmacologic agents available for cervical ripening and labor induction include prostaglandins, misoprostol, 
mifepristone, and relaxin. Prostaglandins cause alteration of extracellular ground substance of cervix by increasing collagenase, elastase, glycosaminoglycan's, and dermatan sulphate and hyaluronic acid levels. ${ }^{3}$ Initiation of uterine contractions is done by smooth muscle relaxation of cervix and gap junctions formation. ${ }^{4,5}$ As per the recommended protocol, $0.5 \mathrm{mg}$ per dose is kept intravaginally up to a maximum of 3 doses 6 hours apart. The goal of induction is to achieve a successful vaginal delivery. Induction to delivery interval has been decreased dramatically by introduction of prostaglandin, and associated complication of fetal infection and amnionitis. ${ }^{6}$ Thus, we planned to study the maternal and fetal outcomes with PGE2 intravaginal gel for induction of labour.

\section{Objectives of this study was;}

- To evaluate the efficacy of instillation of single and multiple doses of PGE2 gel

- To compare the maternal and fetal outcome of various doses

- To study the complications of PGE2 gel.

\section{METHODS}

This prospective study was conducted in the department of obstetrics and gynecology in NIMS hospital in the year 2016-2017. A total of 90 antenatal mothers were taken as participants for this study.

\section{Inclusion criteria}

- $\quad$ Singleton pregnancy

- Gestational age $>37$ weeks

- Cephalic presentation

- Bishops score 1-6

- Reactive fetal heart pattern.

\section{Exclusion criteria}

- Multiple pregnancy

- Gestational age <37 weeks

- Malpresentation

- Previous uterine scar

- Severe medical illness

- Medical condition like glaucoma and asthma

- $\quad$ Patients presenting with bishops score $>6$.

After taking informed consent, and checking the inclusion and exclusion criteria, the study participant was admitted in labour room and bishops score is noted. 0.5 $\mathrm{mg}$ of cerviprime gel was instilled intravaginally in the posterior fornix under aseptic conditions. Fetal heart sound was checked before and after the procedure and women was kept on bed for 30 minutes. After 6 hours bishops score was reassessed and contractions of uterus, if any, are noted. If bishops score was less than 6 , another instillation of gel was done. When score was more than 6 , augmentation with oxytocin was done if required. After second dose, again patient was assessed after 6 hours. The procedure was repeated till onset of labour that is regular uterine contractions, change of bishops score to 6 or more or till 3 instillations of prostaglandin gel.

Patients requiring only 1 dose were called Group 1 and those who were given 2 or 3 doses were called Group 2 . Initial bishops score and after induction scoring was noted and mean score was calculated. Mode of delivery, maternal complication like uterine tachysystole and fetal complications were noted.

\section{Statistical analysis}

Data was analyzed using SPSS software and $\mathrm{p}$ value was obtained.

\section{RESULTS}

Out of 90 cases studied, 65 patients who required only single dose of PGE2 formed Group 1 and 25 needed more than one dose formed Group 2 (Table 1). Outcome was calculated in the form of successful vaginal delivery with no maternal and fetal complications or caesarean section due to certain complications.

Table 1: Groups according to the number of gel insertions and onset of labour.

\begin{tabular}{|ll|l|}
\hline & Number of patients & Percentage \\
\hline Group 1 & 65 & 72.22 \\
\hline Group 2 & 25 & 27.77 \\
\hline
\end{tabular}

Table 2: Variables in both the groups.

\begin{tabular}{|llll|}
\hline Variables & & $\begin{array}{l}\text { Group 1 } \\
(\%)\end{array}$ & $\begin{array}{l}\text { Group 2 } \\
(\%)\end{array}$ \\
\hline \multirow{2}{*}{ Age } & $<30$ years & $55(84.61)$ & $7(28)$ \\
\cline { 2 - 4 } & $>30$ years & $10(15.38)$ & $18(72)$ \\
\hline \multirow{2}{*}{ Parity } & Primigravida & $42(64.61)$ & $12(48)$ \\
\cline { 2 - 4 } & Multigravida & $23(35.38)$ & $13(52)$ \\
\hline $\begin{array}{l}\text { Gestational } \\
\text { age }\end{array}$ & 37-39 weeks & $13(20)$ & $8(32)$ \\
\cline { 2 - 4 } & $>39$ weeks & $52(80)$ & $17(68)$ \\
\hline
\end{tabular}

In Group 1, 84\% patients were less than 30 years of age whereas in Group 2, $72 \%$ were above 30 years of age. $64 \%$ of women in Group 1 were primigravidas and $36 \%$ were multigravidas. In Group 2, $48 \%$ were primigravidas and $52 \%$ were multigravidas. In Group $1,80 \%$ belonged to $>39$ weeks of gestational age and in Group 2, 68\% women were of this gestation. Amongst total participants 54 were primigravidas and 36 were multigravidas (Table 2).

Out of 54 primigravida women, $77.7 \%$ required single instillation and $22.2 \%$ had multiple instillations of PGE2. Out of 36 multigravidas 23 patients $(63.8 \%)$ required single instillation and $13(36.1 \%)$ required multiple doses 
of PGE2. The most common indication for induction of labour in both the groups was post-dated pregnancy followed by prelabour rupture of membranes in Group 1 and maternal medical disorder in Group 2 (Table 3).

Table 3: Indications for induction of labour.

\begin{tabular}{|lll|}
\hline Indications & $\begin{array}{l}\text { Group 1 } \\
(\%)\end{array}$ & $\begin{array}{l}\text { Group 2 } \\
(\%)\end{array}$ \\
\hline Post-dated pregnancy & $23(35.38)$ & $8(32)$ \\
\hline $\begin{array}{l}\text { Prelabour rupture of } \\
\text { membranes }\end{array}$ & $18(27.69)$ & $5(20)$ \\
\hline Obstetric cholestasis & $2(3.07)$ & $0(0)$ \\
\hline $\begin{array}{l}\text { Gestational hypertension } \\
\text { Maternal medical condition } \\
\text { (not severe) chronic } \\
\text { hypertension diabetes }\end{array}$ & $9(13.84)$ & $5(20)$ \\
\hline
\end{tabular}

A total 65 patients received one dose of cerviprime gel forming Group 1. In Group 2, 72\% received 2 doses and $28 \%, 3$ doses of gel (Table 4).

Table 4: No. of gel insertions in different groups.

\begin{tabular}{|c|c|c|c|c|}
\hline & \multicolumn{2}{|l|}{ Group 1} & \multicolumn{2}{|l|}{ Group 2} \\
\hline No. of gel insertion & $\begin{array}{l}\text { No. of } \\
\text { patients }\end{array}$ & $\%$ & $\begin{array}{l}\text { No. of } \\
\text { patients }\end{array}$ & $\%$ \\
\hline One & 65 & 100 & & \\
\hline Two & & & 18 & 72 \\
\hline Three & & & 07 & 28 \\
\hline
\end{tabular}

Initial bishops score mean was 4.2 in Group 1 and 4.1 in Group 2. Mean change in bishop score was analysed after 6, 12, and 18 hours of instillations of PGE2 gel. Significant P-value was obtained in all the groups requiring one, two and three doses of gel (Table 5).

Table 5: Bishops score changes in different groups.

\begin{tabular}{|llllll|}
\hline Bishops score mean & Group 1 & \multicolumn{2}{c|}{ Group 2 } & \multicolumn{2}{c|}{ P-value } \\
\hline & Mean & Standard deviation & \multicolumn{2}{c|}{} \\
\hline After 6 hours & 7.6 & 2.19 & 5.8 & 2.4 & 0.0001 \\
\hline After 12 hours & 9.2 & 2.3 & 7.1 & 3.2 & 0.0001 \\
\hline After 18 hours & 10.0 & 2.18 & 8.2 & 3.5 & 0.004 \\
\hline
\end{tabular}

Table 6: Mode of delivery.

\begin{tabular}{|lll|}
\hline Vaginal delivery & Group 1 & Group 2 \\
\hline $\begin{array}{l}\text { Lower segment caesarean } \\
\text { section }\end{array}$ & $57(87.6)$ & $21(84.0)$ \\
\hline
\end{tabular}

In Group 1, 12.3\% had lower segment caesarean section. In Group 2, 16\% underwent LSCS (Table 6). Complications noted were prelabour rupture of membranes, uterine tachysystole in few cases. Other indications were non reassuring fetal heart rate, meconium stained liquor and non-progress of labour, persistent poor bishops score).

\section{DISCUSSION}

There are various methods to induce labour including medical as well as surgical. PGE2 gel is one of the medical methods of cervical ripening used intracervical as well as intravaginal. Intravaginal instillation of PGE2 gel is known as useful method of cervical ripening for induction of labour. The dose required is much less and the side effects are often acceptable. ${ }^{7,8}$ A single application of PGE2 gel is known to be successful in $83 \%$ to $96 \%$ of cases. Successful use includes both onset of labour and improvement in Bishop score. In our study too we got successful induction in 80 to $90 \%$ of cases in both the groups. However, in about $5 \%$ to $25 \%$ of patients, a single application may not achieve spontaneous labour or cervical ripening. These patients may end as failed inductions. Several workers have attempted to use multiple instillations to overcome the problem of failure with single instillations. Hence in our institution we did this study to assess the success of using multiple dosages of intravaginal PGE2 gel as cervical ripening agent for induction of labour.

Syed N et al, did a study of intracervical PGE2 gel for Cervical Ripening taking 180 subjects and dividing them in two groups on the basis of number of dosages. ${ }^{9}$ In our study 90 cases were studied. 65 patients who required only single dose formed Group 1 and 25 needed more than one dose formed Group 2. Outcome was calculated in the form of successful vaginal delivery with good maternal and fetal outcome or caesarean section due to certain complications. Various factors like age, parity and gestational age were compared in both the groups. In Group 1, 84\% patients were less than 30 years of age whereas in group $2,72 \%$ were above 30 years of age. In Group 1,80\% belonged to > 39 weeks of gestational age and in Group 2, 68\% women were of this gestation. Out of 54 primigravida women, $77.7 \%$ required single instillation and $22.2 \%$ had multiple instillations. Out of 36 multigravidas 23 patients $(63.8 \%)$ required single instillation and $13(36.1 \%)$ required multiple doses. In 
our study we observed that primigravidas required single doses in most cases. That may be attributed to the reason that $80 \%$ of women in Group 1 belonged to lesser age group with gestational age > 39 weeks, since at this gestation initial bishops score is better with more oxytocin receptors in the uterus.

The most common indication for induction of labour in both the groups was post-dated pregnancy (35.38\%) followed by pre-labour rupture of membranes in Group 1 and maternal medical disorder in Group 2. This is comparable with a study done by Warke HS et al, where the most common indication was past dates $(52 \%){ }^{4}$ Bhatla et al, had prolonged pregnancy in $36.25 \% .^{10}$

In this study, 65 patients received one dose of cerviprime gel forming Group 1. In Group 2, 18 women received 2 doses and 7 women 3 doses of gel. Initial bishops score mean was 4.2 in Group 1 and 4.1 in Group 2. Mean change in bishop score was analysed after 6,12 , and 18 hours of instillations of PGE2 gel. Significant P-value was obtained in all the groups requiring one, two and three doses of gel. In a study done by Calder et al, the cervical score had improved from a mean of 2.3 to 6.3 in 6 hours. ${ }^{11}$ This shows that cerviprime gel has a huge impact in improving bishops score. This was comparable to studies done by Rao R et al where initial bishops score was 2.5 to 3 in all the groups and significantly improved with PGE2 gel. ${ }^{12}$

In Group 1, 12.3\% had lower segment caesarean section. In Group 2, 16\% underwent LSCS. Complications noted were pre-labour rupture of membranes, uterine tachysystole in few cases. Other indications were non reassuring fetal heart rate, meconium stained liquor and Non progress of labour, persistent poor bishops score. Mainprize et al, and Bhatla et al, reported caesarean section for fetal distress in $33.3 \%$ of their patients. ${ }^{10,13}$ We had lesser rate of caesarean section and fetal distress occurred in less than $2 \%$ of patients. About $2 \%$ of the newborns in our study had APGAR less than. ${ }^{8}$ This was comparable to other studies.

\section{CONCLUSION}

In the present study PGE2 $0.5 \mathrm{mg}$ gel has been used intravaginally and found to be very effective for cervical ripening. Multiple instillations of gel were proven to have successful labour in primigravida as well as multigravidas. Bishop score improved in both the groups. The maternal risks like infection or uterine tachysystole are not significantly increased by multiple instillations. There is no increased fetal risk with multiple instillations and beneficial if used in appropriately selected cases.
Funding: No funding sources

Conflict of interest: None declared

Ethical approval: The study was approved by the Institutional Ethics Committee

\section{REFERENCES}

1. American College of Obstetricians and Gynecologists. Induction of labor. Practice bulletin no. 10. Washington, D.C.: ACOG; 1999.

2. Edwards RK, Richards DS. Pre-induction cervical assessment. Clin Obstet Gynecol. 2000;43:440-6.

3. Ulmstein, Wingerup L, Anderson. Comparison of prostaglandin E2 gel and intravenous oxytocin for induction of labour. Obstet Gynecol. 1979;54:581-4.

4. Warke HS, Sarogi RM, Sanjawalla SM. Prostaglandin E2 gel in ripening of cervix in induction of labour. J Postgrad Med. 1999;45:105-7.

5. Maillot KV, Stunhsatz HW, Mohanaradhakrishnan V. Changes in glycosaminoglycan distribution in the human uterine cervix during pregnancy and labour. Am J Obstet Gynecol. 1979;135:503-6.

6. Parmar M, Aherwar R, Jahan I. Comparative study of $25 \mathrm{mg}$ vaginal misoprostol versus cerviprime gel for induction of labour at term. Int $\mathbf{J}$ Reprod Contracept Obstet Gynecol. 2014;3(4):887-92.

7. Rayburn WF. PGE2 Gel for cervical ripening and sinduction of labor. Am J Obstet Gynecol. 1989;160:529-33.

8. Zanini A, Ghidini A, Norchi S. Beretta E, Bottinos. Pre-induction cervical ripening with PGE2 gel intracervical vs intravaginal route. Obstet Gynecol. 1990;76:681-3.

9. Bashutheen NS, Sharon M. A study of intracervical PGE2 gel for cervical ripening and induction of labour. Int J Contemp Med Res. 2018;5(3):C4-C7.

10. Bhatla N, Verma A, Buckshee KA. Multiple dose intra cervicalPGE2 gel for cervical ripening. J Obstet Gynaecol Ind. 1997:47-62.

11. Calder AA, Embrey MP. Prostaglandins and the unfavorable cervix. Lancet. 1973;2:1322.

12. Ramana MV, Fathima NMG. A comparative study of single versus multiple instillations of intravaginal PGE2 gel for induction of labour. Indian J Obstet Gynecol Res. 2019;6(3):282-7.

13. Mainprize T, Nimrod C, Dodd G, Persuad D. Clinical utilityof multiple dose administration of PGE2. Am J Obstet Gynecol. 1987;2:341-2.

Cite this article as: Gupta S, Kuntal N, Gupta VK. Maternal and fetal outcomes with the use of prostaglandins E2 as a cervical ripening agent for induction of labour. Int J Reprod Contracept Obstet Gynecol 2020;9:44-7. 